\title{
The effects of work experience during higher education on the labour market entry Learning by doing or an entry ticket?
}

\begin{abstract}
Graduates from higher education often enter the labour market with a considerable amount of work experience. Using German data, we address the question whether early work experience pays off upon labour market entry. We compare the labour market benefits of different types of work experience. This comparison allows us to more generally test hypotheses about different explanations why education pays off. Results indicate that tertiary graduates do not profit from work experience that is unrelated to the field of study or was a mandatory part of the study programme. Even though field-related and voluntary work experience helps graduates to realise a fast integration into the labour market, it is not linked to higher chances for entering a favourable class position or to higher wages in the long run. These results provide evidence for the signalling explanation of educational benefits in the labour market rather than the human capital explanation.
\end{abstract}

\section{Keywords:}

Work experience, Germany, Higher education, Labour market entry 


\section{Introduction}

The transition from school to work is a critical phase in the biography of young adults, as a smooth integration into the labour market is crucial for the subsequent occupational career (Scherer, 2004). Along with educational expansion, job competition among tertiary graduates may be much more tightened as more and more labour market entrants have the same credential. When higher education certificates become less reliable productivity signals, employers may increasingly rely on other more distinct indicators of potential job performance, e.g. social background, in their hiring decisions (Brown, 1995; Jackson, 2001). Higher education research mainly concentrates on the impact of horizontal differentiations by field of study or the quality of institutions on returns upon labour market entry and career advancement (for an overview see Gerber and Cheung, 2008). The effects of extra-curricular characteristics, in particular work experience, on labour market integration are less often considered, even though previous research has highlighted the positive impact of work experience for transitions from unemployment to jobs (Russell and O'Connell, 2001). Given the large share of students working before and during higher education (Isserstedt et al., 2010), a part of the gross returns to education could actually be returns to previous work experience (Roksa and Velez, 2009). For instance, the 'Reflex-survey' of higher education graduates in Europe shows that $79 \%$ of higher education graduates in Germany took part in a work placement or internship during their studies (Allen and Van der Velden, 2009). Since work experience in its extent and type varies by social background (Isserstedt et al., 2010), scrutinizing its labour market effects also has significance for the debate on inequality in higher education. Prior research, which focuses on narrowly defined graduate populations or which is rather descriptive in its analytical strategy, suggests that labour market returns of early work experience largely depend on its type. While field-related work experience tends to affect the labour market performance in a positive way, non-field-related jobs or mandatory internships have either no or even negative effects (Allen and Van der Velden, 2009; Blasko et al., 2002; Klein and Weiss, 2011; Robert and Saar, 2012). However, few studies consider the effects of different types of early work experience in a comprehensive way and scrutinise the mechanisms behind varying payoffs in the labour market. From a theoretical point of view, a comparison of different types of work experience is highly informative. The human capital framework assumes a positive effect of work experience in general and irrespective of its specificity or voluntariness. By contrast, the signalling approach stresses that employers decide which characteristics are perceived as productive and which are not. Due to imperfect information, employers will only take those individual traits as productivity-signals into 
account that are assumed to indicate either decreasing training costs, e.g. occupation-specific work experience, or preferable unobserved traits, e.g. the voluntary decision to participate in work experience.

In order to disentangle these different mechanisms, we estimate the effects of having a job as student assistant, other field-related work experience during studies, mandatory internships, non-field-related employment during studies, and employment before university enrolment on several outcomes indicating the smoothness of transition into employment: search duration until the first significant job, occupational class destination, and hourly wages five years after graduation. We analyse Graduate Panel 1997 data that were collected by the German HIS (Hochschul-Informations-System).

\section{How does work experience before graduation affect labour market returns?}

Several theories attempt to explain why education or work experience entails positive labour market outcomes (see Bills, 2003 for an overview). When considering work experience in a broad sense, the different theoretical approaches expect a positive impact on returns, even though the underlying mechanisms differ. Hence, only the comparison of different types of work experience that vary in the provision of skills or in their signalling capacity will enable us to find the mechanisms behind job allocation. In the following, we discuss the implications of human capital, cultural capital, social networks and signalling theory for early work experience pay-offs in the labour market. We then empirically test contradictory hypotheses of the human capital and signalling approach.

\section{Credentialism}

According to credentialist arguments, access to occupational positions is organised by processes of occupational closure (Weeden, 2002). The most prominent closure mechanism is educational credentialing, assuming that employers 'operate on widely shared societal assumptions about the appropriate relationship between schooling and job assignment' (Bills, 2003, p. 452). Further, they collectively maintain the corresponding barriers to jobs by legal constraints of certification and less legalised traditions (e.g. Bol and Van de Werfhorst, 2011). Given this situation, employers do not consider other individual characteristics such as gender, social background or work experience, in hiring decisions or salary negotiations but strictly follow the rules of allocating educational degree-holders to the corresponding occupations. Exclusive 'credentialist hiring' (Bills and Brown, 2011, p. 1) then leads to the fact that educational credentials are the only effective assets job applicants can rely on. As a 
consequence, neither work experience nor its type affects the labour market performance. Hence, hypothesis 1 posits that work experience before graduation, irrespective of its type, has no impact on the transition from higher education to work.

\section{Early work experience as form of human capital}

According to the human capital approach, a job applicant's productivity is directly determined by his or her individual skills or knowledge, inasmuch as they increase labour productivity. As employers pay their workers according to their individual productivity, individuals' wages increase the more skilled they are. The human capital stock originates from different sources, most prominently from schooling. Besides, it is discussed as one of the main mechanisms for the effectiveness of further training (e.g. Dieckhoff, 2007; O'Connell and Byrne, 2012; Sieben, 2007). Mincer (1974) pointed out that work experience is a major source of individual productivity. From a broad understanding of the human capital theory, any work experience, irrespective of its type, conveys skills or knowledge improving future job productivity. Thus, any work experience during studies is an additional accumulation of human capital and should be rewarded in the labour market. Hence, we expect a positive effect of any work experience before graduation on labour market returns (hypothesis 2).

However, an employee's skill profile is composed of various elements that may be more or less valuable in specific jobs. For different labour market contexts research has shown that matching outcomes are highly dependent on the type of accumulated skills (e.g. Sieben, 2007). For instance, Robert and Saar (2012) also show that field-specific skills obtained at university are important for subsequent labour market returns. Aside from training in specific fields of study, early work experience in a workplace that matches the field of study could further enhance the acquisition of occupation-specific skills. These experiences may increase graduates' employability which the higher education system, concentrating on general skills, may not provide (Wilton, 2011). This suggests that in particular field-specific work experience enhances productivity and thus has positive effects on labour market outcomes.

Whether human capital is the sole criterion for the selection of employees is mainly questioned in sociological literature (Goldthorpe, 1996). Work experience can also introduce individuals into the cultural environment at the workplace and help to build social relationships with employers and gatekeepers to the labour market. Bourdieu (1986) stresses the importance of cultural codes, behavioural patterns and habits. For instance, good manners might ease the communication with firms in general. Knowing firm-specific cultural codes 
may be advantageous in job interviews. Cultural resources acquired in field-specific work may be relevant for accessing adequate occupational positions, while resources gained in nonfield-specific work may be less useful for the academic labour market.

Information about job opportunities and job characteristics might be provided by social ties established at the workplace (Granovetter, 1974). The type of employment has been identified as a key factor determining the relevance of network resources (Weiss and Klein, 2011). Social ties acquired in field-specific work experience provide resources that are helpful for the job search on the academic labour market. In contrast, ties into areas that do not provide field-related work experience may help at best to prevent unemployment, but clearly do not improve the quality of the job.

From the discussion of these three resources (occupation-specific human capital, cultural capital, and social capital) we conclude the following: work experience before graduation has a positive impact on labour market returns when it is field-related and students acquire occupation-specific resources (hypothesis 3).

\section{Is work experience before graduation merely a signal?}

In contrast to the human capital approach, the signalling theory stresses employers' difficulties to recognise job applicants' real productivity due to an asymmetry of information (Spence, 1973). Since job applicants' productivity is unknown, employers must rely on proxies. Employers can also learn from previous experiences and adapt their hiring behaviour to new beliefs and perceptions. Qualitative evidence highlighted the importance of educational credentials as signals for general abilities and the willingness to learn even for such knowledge-intensive sectors as information technology (Adams and Demaiter, 2008). Aside from educational credentials, employers may value other individual characteristics such as social origin, appearance or letters of recommendation as productivity signals. The need for differentiation among tertiary graduates by other signals is expected to increase when educational credentials inflate (Brown, 1995).

Whether work experience before graduation is rewarded upon labour market entry depends on how employers' interpret this signal. Field-related work experience could be perceived as a better indication of potential training costs than non-field-related work experience since the obtained skills are more likely to fit the job requirements. ${ }^{i}$ Early work experience that is field-related can also serve as probation period in which employers screen potential job applicants and thus reduce uncertainty about his or her productivity (Stieglitz, 1975). Therefore, the signalling approach implies the same expectation as the occupation- 
specific interpretation of the human capital theory: we assume a positive effect of work experience before graduation only when it is related to the field of study.

Ideally, however, we want to test human capital and signalling approach against each other. In general, this is difficult to achieve with individual-level data and has not often been convincingly done in previous research (Bills 2003). We recognise two ways for going beyond the third hypothesis and for identifying contradictions between these two mechanisms. The first strategy is to differentiate between voluntary and mandatory work experiences that are related to the field of study. We see no plausible reason why voluntary and mandatory work experiences, on average, would differ in terms of human capital accumulation. From the signalling approach, however, only voluntary work experience should be a relevant signal for employers. If employers look for hidden characteristics that increase productivity, such as motivation or commitment, they may prefer graduates who were working on a voluntary basis. Due to its obligatory nature, mandatory work experience does not indicate the graduates' effort, initiative or motivation. Hence, from a signalling perspective, only voluntary work experience has a positive effect on labour market outcomes (hypothesis 4a). ${ }^{\mathrm{ii}}$

The second strategy refers to short-term vs. long-term effects. The human capital approach would propose long-term effects of work experience; the signalling approach would suggest only short-term effects of work experience in the matching process upon labour market entry. While signals improve graduates' standing in employers' hiring decisions, human capital enhances productivity on the job. If work experience before graduation enhances human capital, it should have long-lasting effects on the working career. If only used as a signal, the benefits should be restricted to the hiring process (cf. Ishida et al., 1997). From the signalling theory we can derive hypothesis $4 b$ that work experience improves the labour market integration but has no effect on returns five years after graduation.

\section{Is Germany a unique case?}

Regarding higher education, we do not adopt the common assumption that labour market transitions are smoother and faster in Germany than in other contexts due to a high degree of occupational specificity (Dieckhoff, 2008; Hillmert, 2002). Although there are linkages between several programmes of higher education (e.g. professional degrees) and occupational positions (Leuze, 2007), the German higher education system is much less occupation-specific than the dual system of apprenticeship. In addition, employers are neither involved in the curricula at higher education institutions nor do higher education studies 
include practical training and presence at workplaces on a regularly basis. University education in Germany is rather elitist and provides academic skills, while Fachhochschulen provide higher education with a more practical, somewhat stronger vocational focus (Mayer et al., 2007). However, in contrast to other countries, vocational programmes, such as nursing or kindergarten teacher, are excluded from higher education and trained in the dual apprenticeship system. In international comparison, the degree of vocational orientation in higher education in Germany appears to be as pronounced as in other countries. This applies to an even greater extent to our analysis sample, as we have excluded Staatsexamengraduates, which account for the group of professionals (see our section on Data and Sample). Furthermore, higher education in Germany expanded much less than in other countries (Müller and Wolbers, 2003). Since higher education certificates have kept their strong signalling capacity, a differentiation among higher education graduates, e.g. by field of study, should be less important in Germany than in countries with a stronger expansion of higher education (Kim and Kim, 2003). Accordingly, by cross-national comparison the association between educational attainment and labour market rewards is remarkably high in Germany (Müller et al., 1998).

Furthermore, the labour market was able to keep pace with the educational expansion and absorbs the increasing number of higher education graduates in adequate occupational positions (Klein, 2011). Since more or less all higher education graduates integrate smoothly into the labour market, additional signals such as early work experience may be less decisive. Therefore, we argue that the German institutional context allows for a rather conservative test of the effects of early work experience among higher education graduates.

On the other hand, we acknowledge that in Germany, as in other contexts, the distinctive value of higher education could have decreased over the last decades. At present, an increasing share of graduates does not work anymore in traditional professions or higher grade public service positions. Instead, they are now more often employed in high-skilled positions in private industry, e.g. in managing positions, as analysts, computer -, marketing or sales experts, that were created during a process of occupational upgrading (Klein, 2011). Thus, graduates may increasingly work in occupations for which they are less well prepared by their academic studies and which require more practical skills or 'soft skills' (Jackson et al., 2005). The relevance of early work experience may be further strengthened by the fact that full-time work experience is rather uncommon among higher education graduates in Germany than, e.g., in the US (Jacob and Weiss, 2010). In addition, some need for distinction might be stimulated by the low variation in prestige of German higher education institutions. 
Status differences are mostly reduced to the two-tier structure with upper-tier full research universities and lower-tier Fachhochschulen (Teichler, 1993).

The role of work experience may be somewhat different for the Fachhochschulen. These institutions teach applied fields, mainly social work, business administration and engineering (Huisman, 2003, p. 15). Due to their vocational orientation, early work experience could be more valuable for jobs that Fachhochschule graduates attain. By contrast, the Fachhochschule may already teach the required practical skills in such a way that early work experience is unable to further enhance productivity. Both arguments justify separate analyses by institutional types as a consistency check of our results.

\section{Data, variables and methods}

\section{Data and sample}

We analyse data from the German HIS (Hochschul-Informations-System) Graduate Panel 1997 (Fabian and Minks, 2006). This mail survey involved interviews with 6,216 graduates from higher education interviewed one and five years respectively after graduation.

For various purposes the sample is restricted to specific study programmes. First, we exclude fields of study that are certified with a Staatsexamen-degree and lead into professions (medical doctors, veterinaries, clerics, lawyers, pharmacists, and teachers). While the theoretical education and examination is undertaken in universities, the state assigns additional practical training and examination in a second educational stage (Referendariat). Graduates from these programmes could thus interpret their Referendariat as a mandatory internship. Excluding them also appears to be necessary since the transition to the labour market is highly institutionalised and organised by the state. There is hardly any room for employer considerations like in private sector occupations. For instance, teachers are assigned to public schools by state authorities. Thus, the hiring mechanisms we discussed above are less applicable.

Furthermore, we exclude all respondents in study programmes where 85 per cent of the graduates or more have participated in mandatory internships. This is because counterfactual analysis requires some "randomness" in the assignment of treatment and control group (Caliendo and Kopeinig, 2008, p. 38). From a practical perspective, we will hardly find matching observations in the control group if almost everyone in a specific field completed a mandatory internship. Since we are interested in a comparison of the effects of different work experiences, we use the adjusted sample for every other treatment as well. The 
theoretical mechanisms we assume to be at work would anyhow be diluted if work experience was universal. After excluding these respondents, the sample consists of 2,252 cases.

\section{Dependent variables}

We operationalise labour market returns by using three different variables: search duration until the first significant job, class position, and log hourly wages five years after graduation. Job-search duration is measured as the "number of months between graduation and job-entry'. A significant job can be either self-employment or dependent employment, but it excludes short-term and marginal employments ('freelance work', 'casual job', 'internship', 'advanced training', and 'family work'). ${ }^{\text {iii }}$ The activities 'miscellaneous' and 'parental leave' are not considered as search time; time spent in these statuses has been ignored. Only $1.67 \%$ of all graduates report no significant job within five years after graduation. Due to such a small number of right-censored cases, we did not estimate event history models.

The wage five years after graduation serves as a long-term indicator for labour market success. We code the dependent variable as the natural logarithm of the gross hourly wage, including annual bonuses. The second long-term indicator is the class position five years after graduation. Class is considered as a more stable indicator of career advancement than wages. The class position is operationalised with the European Socio-economic Classification (Rose and Harrison, 2007). For tertiary graduates, service class positions are adequate occupational class destinations. A service relationship involves not just a salary and various perquisites, but also prospective elements such as promotion opportunities. Therefore, we concentrate the analysis on access chances to the service class (upper and lower, i.e. ESeC 1 and 2).

\section{Independent variables}

Our independent variables are summarised in Table 1. As central independent variables we consider five different types of work experience: two non-field-related treatments (work experience before university enrolment ${ }^{i v}$ and non-field-related work experience during studies) and three field-related treatments (student assistance, other field-related work during studies, and mandatory internship). Whether work experience is field-related or not was selfreported by the graduates. ${ }^{\mathrm{v}}$ Respondents who reported to have work experience were asked in a second step whether they had work tasks that were in a broader sense related with their field of study or their preferred occupation (Hatten Sie darunter Jobs bzw. Tätigkeiten, die im weiteren Sinne fachlich etwas mit Ihrem Studium oder Ihrem angestrebten Berufsfeld zu tun haben?). Aside from the listed selection variables, we additionally consider the respondents' 
assessment of the study programme, e.g. in terms of the degree of structuring and how up to date the acquired methods are, in order to control for quality differences between institutions. To save space within this journal, Table 1 does not include the distribution of all independent variables. A full version of the Table can be downloaded at XXXXX.XX.

\section{TABLE 1 here}

\section{Estimation strategy}

In order to hold confounding factors constant and take self-selection into account, we use propensity score matching (Leuven and Sianesi, 2003). We are aware that the design can only control for observable traits and does not account for unobserved heterogeneity. It has, though, an advantage over parametric regression models by relaxing the strong assumptions regarding the functional forms of various effects in a model (Rosenbaum and Rubin, 1983). Furthermore, inference on groups which are not covered by the common support are ruled out. Group differences are estimated in two steps. First, we estimate assignment models for the propensity of all individuals to be in the treatment group based on potentially confounding variables. Second, the obtained propensity score is used to match the treated individuals with similar individuals in the control group. In this way, the distribution of potentially confounding variables between treatment and control group is balanced. An exemplary assignment model (for having non-field-related work experience before studies) is shown in Table 2. ${ }^{\mathrm{vi}}$ The average effect of a treatment (in our case various kinds of work experience) is now estimated by comparing the differences in outcomes between the matched individuals in the treatment and the control group. We first estimate propensity scores for each individual by running a logistic regression model of each respective treatment on a large set of individual attributes and characteristics of the higher education institution which are all summarised in Table 1.

The matching based on the propensity score can be done in different ways. Here, we apply the Kernel Matching Method with an Epanechnikov-kernel (Heckman et al., 1997). This method matches respondents from the treatment group to a weighted average of graduates in the control group. The weights are inversely proportional to the distance between the propensity scores of treated individuals and non-treated individuals.

We are aware that there is a risk of not accounting for all potentially important covariates due to a lack of information in the data. Although the set of pre-existing covariates appears to be quite comprehensive, unobserved heterogeneity may never be fully ruled out 
and prevents us from interpreting our findings causally. A problem might be that we have no prospective information on intelligence and thus have to rely on school marks. Also, we do not measure motivation before enrolment in higher education. However, any omitted variable that could significantly change the results would have to be quite a powerful predictor for work experience and labour market outcomes. In this regard, we want to highlight that our results are more conservative than previous studies, since our data has much more information and a larger sample than their databases (Allen and Van der Velden, 2009; Robert and Saar, 2012; Wilton, 2011).

\section{Results}

Our results are summarised in Table 3. For every outcome we first report the unmatched differences between 'treated' and 'untreated' individuals, i.e. the gross differences in labour market performance between the group who acquired a certain type of work experience and the one that did not. The row entitled "ATT" shows the Average Treatment Effect on the Treated (ATT) after matching.

When comparing graduates with non-field-related work experience before studies to those without, we find, if at all, small differences in all three outcomes. This holds true for the unmatched comparison as well as for the results of the matching models.

With regard to non-field-related work experience during studies a small (although not significant) disadvantage in terms of wages and class position for the treated individuals prevails after matching. As to job search duration, graduates with non-field-related work experience during studies search longer for their first significant job than their counterparts without this experience. This difference is significant for a comparison of unmatched as well as matched cases (z-value 2.97). In sum, for graduates with non-field-related work experience we do not find any significant impact on wages and class position, but significantly longer job search durations.

Aside from work as a student assistant, work experience that is field-related and voluntary shows a strong positive effect on hourly wages, however, only under the comparison without propensity score matching. When we match, the difference is much smaller (z-value 1.86). Hence, one has to doubt the robustness of the bivariate finding in the light of omitted variable bias. The same pattern applies to the case of service class positions. There seem to be advantages for those who worked in field-specific jobs over the comparison group in the unmatched condition. In the matched comparison, however, the effect is clearly reduced with a bootstrapped z-value of only 1.12. The advantages in the job search duration 
of graduates with field-specific work experience are strong and significant in the unmatched comparison. For this outcome, however, the ATT, although slightly smaller, remains significant. Thus, field-specific work experience significantly shortens job search duration, but does not have a significant impact on the probability of attaining service class positions or on wages five years after graduation.

The effect of student assistance on hourly wages is small in the unmatched comparison as well as after matching. The initially positive effect on entering the service class is clearly reduced under the matched condition with a bootstrapped z-value of 1.85. A positive and significant effect of working as a student assistant that prevails after matching is only found in the case of search duration. Former student assistants find a job much faster than graduates without this experience. To sum up, student assistants - as graduates with other field-related work experience - on average need a shorter time to find a job but do not have advantages in entering the service class or realizing higher wages five years after graduation.

Finally, we considered the effects of mandatory internships. The results show that differences between graduates can only be observed in bivariate comparisons. Hence, mandatory internships do not have a significant impact, neither on job search duration nor on outcomes five years after graduating when graduates' other characteristics are taken into account.

All analyses were conducted separately for Fachhochschule and university graduates (models indicated in online-appendix). While the Fachhochschule samples are small and estimation is difficult, the principle pattern of findings could be replicated for both types of institutions. A major difference is the much greater positive value of student assistance on job search time among university graduates. This, however, is not surprising as universities often employ student assistants as researchers or $\mathrm{PhD}$-students after graduation. By contrast, Fachhochschulen cannot offer such opportunities since they do not have a large body of research staff and cannot award $\mathrm{PhDs}$.

\section{TABLE 3 here}

Several theoretical approaches suggest different mechanisms, but arrive at a similar hypothesis: work experience, in particular when related to the field of study, should have positive effects on labour market integration. The exception is the credentialist expectation of non-effects (hypothesis 1). This viewpoint is challenged by our results showing that fieldspecific work experience and student assistance significantly reduces job search duration. 
Nevertheless, hypothesis 2, which was derived from a general reading of human capital theory and ignored the field-specificity of resources collected through work, cannot be confirmed either. According to this, any work experience should have positive effects on labour market returns. Our findings show that this claim is too general, since non-field-related work experience during and before studies does not pay off in terms of labour market rewards.

In contrast, hypothesis 3 postulates that only field-specific work experience has positive effects on labour market performance. Working in such jobs may increase an individual's productivity by conveying specific occupational skills and knowledge, specific cultural and social capital in a relevant sub-labour market. At first glance, our results support this claim since field-related work experience shortens the job search duration while nonfield-related work experience does not. However, this finding is further restricted to voluntary work experience and does not apply to mandatory internships. Moreover, voluntary fieldrelated work experience has no significant effects on the long-term indicators class position and wages. Hence, hypotheses $4 \mathrm{a}$ and $4 \mathrm{~b}$ cannot be rejected. This supports the signalling approach: work experience is used as a signal in the labour market entry period and has no long-lasting effects via increased productivity.

Work experience before studies seems to play a different role compared to work experience during studies. While non-field-related work experience before studies has no effect on all three outcomes, non-field-related work experience during studies significantly prolongs the job search duration and has somewhat negative effects on wages as well as on class position five years after graduation. This could be due to the fact that all students initially search for a job that matches their field of study. If this fails, students with non-field related work experience may draw on social networks and accept a non-matching job. Nevertheless, the disadvantages in class positions and wages compared to those without nonfield-related work experience are insignificant.

\section{Discussion and Conclusion}

In essence, we find that only field-related and voluntary work experience has positive effects on labour market integration while non-field-related and field-related mandatory work experiences have no effect and in some cases even a negative one. This result is in line with previous research on central and eastern European countries (Robert and Saar, 2012) as far as short-term effects are concerned. Regarding labour market returns five years after graduation, however, we do not find pay-offs for any type of work experience. Most effects of work 
experience disappear when we match on propensity scores. Our findings have several implications for the debate on the mechanisms behind labour market returns to work experience or education.

First, our results contradict the credentialist perspective since we find effects of characteristics that are not credentials. In defence of credentialism it should be acknowledged that credentials, in this case tertiary degrees, are constant in our sample. Probably, the effects of formal education are still the major determinant of labour market outcomes, particularly in Germany. Nevertheless, extra-curricular activities seem to matter in addition. The finding is consistent with research on further education and training, indicating that non-certified education has positive labour market effects, too (Dieckhoff, 2007; O'Connell and Byrne, 2012). At the same time, pre-graduation work experience has no significant long-term effects on the occupational position or wages. Probably, the effects of early work experience are superimposed by the effect of actual work experience and fade away during the working career.

Second, non-field-related work experience has no effects on wages and occupational class position five years after graduation. This conclusion is equally in line with a narrow human capital perspective and the signalling approach. Interestingly, non-field-related work experience during studies shows significant negative effects on search duration. Possibly, students cannot devote as much time to their studies or their search for a job after graduation due to their high workload during studies. An alternative interpretation would be that those students, who are less interested in their studies and perform poorly, are the ones doing nonfield-related work more often. Although we control for a large set of variables to make groups as comparable as possible, motivational factors are hard to grasp and omitted variables cannot be fully ruled out.

Third, we find that only field-related voluntary work experience has positive effects on labour market outcomes. On the one hand, this finding may indicate that employers use only voluntary work experience as a signal. It would contradict the human capital perspective that any accumulation of human capital irrespective of its voluntariness or field-relevance increases productivity. It also questions the assumption that specific human capital results in a better labour market performance. Mandatory internships are always field-specific and should lead to the same human capital accumulation as voluntary internships. If employers use early work experience as an indication for personal traits such as motivation or commitment, the signalling capacity of mandatory internships is lower than the value of voluntary work experience, as every student in a programme completes them. On the other hand, the 
difference between the effects of mandatory and voluntary work experience may again just point to the fact that graduates with voluntary work experiences have better labour market outcomes due to an unobserved heterogeneity in ability, motivation or commitment. For mandatory internships self-selection is ruled out by being compulsory. Regardless of the mechanisms, from a policy perspective the implementation of mandatory internship experiences in higher education curricula should be questioned. Time and support for collecting voluntary and field-specific work experience appear to be more beneficial for students.

Fourth, voluntary field-related work experience has strong effects on job search duration and rather weak effects on the long-term indicators wages and occupational position five years after graduation. This result also speaks for the signalling perspective, since human capital should have rather persisting effects across the occupational career. Early work experience as a signal should have rather short-term effects on success upon labour market entry, when other signals that become relevant during the working career are still absent. Finally, student assistance plays a rather unique role for labour market integration: it shortens job search duration and increases the probability of working in service class positions.

From a theoretical point of view, these results stress that human capital accumulation does not increase labour market returns in an automatic way, but depends on whether employers use education or work experience as signals for productivity. It is important to note that employers decide which individual characteristics they consider as productive value. Our findings on the significance of voluntariness are in line with a number of recent findings from labour market research on the importance of non-cognitive traits such as perseverance, trustworthiness, motivation or tenacity for stratification processes (Farkas, 2003; Jackson et al., 2005). With the expansion of educational credentials (Brown, 1995), additional signals for unobserved traits, such as the initiative to voluntary work, may become increasingly relevant.

One could further ask whether our findings have at least some implications for labour market policy in general. Bringing back workers into any kind of job might not help them to reintegrate into the labour market as well as bringing them back into jobs that match their education would. However, high-skilled and low-skilled labour markets might work differently with regard to job requirements and signals, and thus further research should investigate the role of specific types of work experience, in particular among the lower labour market segments.

Finally, our findings contribute to the debate on inequality in higher education. The known reliance of working class children on their own work for financing higher education 
pushes them more often into non-field related jobs (Isserstedt et al., 2010). If work experience would ease labour market integration in general, this could counterbalance other disadvantages of lower class students. But this does not seem to be the case. Only studyrelated voluntary work experience seems to be beneficial upon labour market entry, albeit to a small degree. This finding suggests that financial aid for students should aim at reducing the need to take up unskilled, non-field related jobs in order to reduce inequalities in higher education. Otherwise, lower class students may more often have to work in non-related jobs to make their living, going along with further disadvantages on the labour market after graduation.

Should we expect that these results are limited to the German context where labour market entry appears to be smooth even for less specifically trained higher education graduates? We suggest no, since we identify only small differences between German and other higher education systems regarding the curricular particularities which have been made responsible for the smooth labour market integration of secondary education vocational graduates in Germany. To draw a more informed conclusion on the impact of the institutional setting on the role of early work experience for the labour market entry, we would need to engage into comparative institutional research. This has to be left for future research. 


\section{References}

Adams, TL and Demaiter, EI (2008). Skill, education and credentials in the new economy: The case of information technology. Work, Employment and Society 22(2): 351-362.

Allen, J and Van der Velden, RKW (Eds.) (2009). Competencies and early labour market careers of higher education graduates. Ljubljana: HEGESCO. http: \www.hegesco.org/content/view/36/108/.

Bills, DB (2003). Credentials, signals, and screens: Explaining the relationship between schooling and job assignment. Review of Educational Research 73(4): 441-469.

Bills, DB and Brown, DK (2011). New directions in educational credentialism. Research in Social Stratification and Mobility 29(1): 1-4.

Blasko, Z Little, B and Woodley, A (2002). UK graduates and the impact of work experience, Centre for Higher Education Research and Information (CHERI).

Bol, T and Van de Werfhorst, HG (2011). Signals and closure by degrees: The education effect across 15 european countries. Research in Social Stratification and Mobility 29(1): 119-132.

Bourdieu, P (1986). The forms of capital. In JG Richardson (Ed.), Handbook for theory and research for the sociology of education (241-258). New York: Greenwood Press.

Brown, P (1995). Cultural capital and social exclusion: Some observations on recent trends in education, employment and the labour market. Work, Employment and Society 9(29): 29-51.

Caliendo, M and Kopeinig, S (2008). Some practical guidance for the implementation of propensity score matching. Journal of Economic Surveys 22(1): 31-72.

Dieckhoff, M (2007). Does it work? The effect of continuing training on labour market outcomes: A comparative study of germany, denmark, and the united kingdom. European Sociological Review 23(3): 295-308.

Dieckhoff, M (2008). Skills and occupation attainment: A comparative study of germany, denmarkt and the uk. Work, Employment and Society 22(1): 89-108.

Fabian, G and Minks, K-H. (2006) Dokumentation des scientific use files "hisabsolventenpanel 1997" HIS Dokumentation. Hannover: Hochschul-InformationsSystem.

Farkas, G (2003). Cognitive skills and noncognitive traits and behaviors in stratification processes. Annual Review Sociology 29: 541-562.

Gerber, TP and Cheung, SY (2008). Horizontal stratification in postsecondary education: Forms, explanations, and implications. Annual Review Of Sociology 34: 299-318.

Goldthorpe, JH (1996). Problems of "meritocracy". In R Erikson and JO Jonsson (Eds.), Can education be equalized? The swedish case in comparative perspective (255-288). Boulder Colorado: Westview Press.

Granovetter, MS (1974). Getting a job. A study of contacts and careers. Cambridge: Harvard University Press.

Heckman, JJ Ichimura, H and Todd, P (1997). Matching as an econometric evaluation estimator: Evidence from evaluating a job training programme. Review of Economic Studies 64(3): 605-654.

Hillmert, S (2002). Labour market integration and institutions: An anglo-german comparison. Work Employment and Society 16(4): 675-701.

Huisman, J. (2003) Country report - higher education in germany CHEPS - higher education monitor. Twente: Center for Higher Education Policy Studies.

Ishida, H Spilerman, S and Su, K-H (1997). Educational credentials and promotion chances in japanese and american organizations. American Sociological Review 62(6): 866-882.

Isserstedt, W Middendorff, E, et al. (2010). Die wirtschaftliche und soziale lage der studierenden in der bundesrepublik deutschland 2009. 19. Sozialerhebung des 
deutschen studentenwerks. Berlin: Bundesministerium für Bildung und Forschung (BMBF).

Jackson, M (2001). Non-meritocratic job requirements and the reproduction of class inequality: An investigation. Work, Employment and Society 15(3): 619-630.

Jackson, M Goldthorpe, JH and Mills, C (2005). Education, employers and class mobility. Research in Social Stratification and Mobility 23: 3-33.

Jacob M, Weiss F (2010) From Higher Education to Work: Patterns of Labor Market Entry in Germany and the US. Higher Education 60(5): 529-542.

Kim, A and Kim, K-W. (2003) Returns to tertiary education in germany and the uk: Effects of fields of study and gender: Mannheimer Zentrum für Europäische Sozialforschung.

Klein, M (2011). Trends in the association between educational attainment and class destinations in West Germany: Looking inside the service class. Research in Social Stratification and Mobility 29(4): 427-444.

Klein M, Weiss F (2011) Is forcing them worth the effort? Benefits of mandatory internships for graduates from diverse family background at the labour market entry. Studies in Higher Education 36(8): 969-987.

Leuven, E and Sianesi, B (2003). Psmatch2: Stata module to perform full mahalanobis and propensity score matching, common support graphing and covariate imbalance testing. (Version 4.0.5). http://ideas.repec.org/c/boc/bocode/s432001.html

Leuze, K (2007). What makes for a good start? Consequences of occupation-specific higher education for career mobility. International Journal of Sociology 37(2): 29-53.

Mayer, KU Müller, W and Pollak, R (2007). Germany: Institutional change and inequalities of access in higher education. In R Arum A Gamoran and Y Shavit (Eds.), Stratification in higher education: A comparative study (241-265). Palo Alto: Stanford University Press.

Mincer, J (1974). Schooling, experience and earnings. New York: Columbia University.

Müller, W Steinmann, S and Ell, R (1998). Education and labour-market entry in germany. In Y Shavit and W Müller (Eds.), From school to work. A comparative study of educational qualifications and occupational destinations. (143-188). Oxford: Clarendon Press.

Müller, W and Wolbers, MHJ (2003). Educational attainment in the european union: Recent trends in qualification patterns. In W Müller and M Gangl (Eds.), Transitions from education to work in europe (23-62). Oxford: Oxford University Press.

O'Connell, PJ and Byrne, D (2012). The determinants and effects of training at work: Bringing the workplace back in. European Sociological Review 28(3): 283-300.

Robert, P and Saar, E (2012). Learning and working: The impact of the 'double status position' on the labour market entry process of graduates in cee countries. European Sociological Review Advance Access. doi: 10.1093/esr/jcr091

Roksa, J and Velez, M (2009). When studying schooling is not enough: Incorporating employment in models of educational transitions. Research in Social Stratification and Mobility 28(1): 5-21.

Rose, D and Harrison, E (2007). The european socio-economic classification: A new social class schema for comparative european research. European Societies 9(3): 459-490.

Rosenbaum, PR and Rubin, DB (1983). The central role of the propensity score in observational studies for causal effects. Biometrika 70(1): 41-50.

Russell, H and O'Connell, PJ (2001). Getting a job in europe: The transition from unemployment to work among young people in nine european countries. Work, Employment and Society 15(1): 1-24.

Scherer, S (2004). Stepping-stones or traps? The consequences of labour market entry positions on future careers in west germany, great britain and italy. Work, employment and society 18: 369-394. 
Sieben, I (2007). Does training trigger turnover - or not?: The impact of formal training on graduates' job search behaviour. Work, Employment and Society 32(3): 397-416.

Spence, M (1973). Job market signaling. Quarterly Journal of Economics 87(3): 355-374.

Stieglitz, JE (1975). The theory of "screening", education, and the distribution of income. The American Economic Review 65: 283-300.

Teichler, U (1993). Diversity in higher education in germany: The two-type structure. In LV Meek L Goedegebuure, et al. (Eds.), The mockers and mocked: Comparative perspectives on differenciation, convergence and diversity in higher education (117137). Oxford: Pergamon.

Weeden, KA (2002). Why do some occupations pay more than others? Social closure and earnings inequality in the united states. American Journal of Sociology 108(1): 55101.

Weiss F, Klein M (2011) Soziale Netzwerke und Jobfindung von Hochschulabsolventen - Die Bedeutung des Netzwerktyps für monetäre Arbeitsmarkterträge und Ausbildungsadäquatheit. Zeitschrift für Soziologie 40(3): 228-245.

Wilton, N (2011). Do employability skills really matter in the uk graduate labour market? The case of business and management graduates. Work, Employment and Society 25(1): 85-100. 
Table 1 Summary statistics and variables included in different assignment models (grey: included in respective model)

\begin{tabular}{|c|c|c|c|c|c|c|}
\hline & $\begin{array}{c}\text { Non-field- } \\
\text { related, } \\
\text { before } \\
\text { studies }\end{array}$ & $\begin{array}{l}\text { Non-field- } \\
\text { related, } \\
\text { during } \\
\text { studies }\end{array}$ & $\begin{array}{c}\text { Field- } \\
\text { related, } \\
\text { during } \\
\text { studies }\end{array}$ & $\begin{array}{c}\text { Student } \\
\text { assistant }\end{array}$ & $\begin{array}{l}\text { Mandatory } \\
\text { internship }\end{array}$ & $\begin{array}{l}\text { Mean / } \\
\text { share }\end{array}$ \\
\hline$\overline{\text { Age }}$ & & & & & & 27.68 \\
\hline Year of eligibility to university & & & & & & 1989.24 \\
\hline Female & & & & & & 0.60 \\
\hline GPA: Abitur (10:excellent to 40 :sufficient) & & & & & & 22.10 \\
\hline Parenthood before eligibility to university & & & & & & 0.01 \\
\hline Parents with higher education degree & & & & & & 0.45 \\
\hline Federal state: Abitur & & & & & & online* \\
\hline Type of Abitur & & & & & & online* \\
\hline Type of upper secondary school & & & & & & online* \\
\hline Field of study: & & & & & & \\
\hline Agricultural/nutritional sciences/FH** & & & & & & 0.03 \\
\hline Electrical engineering/FH & & & & & & 0.08 \\
\hline Computer science/FH & & & & & & 0.03 \\
\hline Economics/FH & & & & & & 0.08 \\
\hline Agricultural/nutritional sciences/Uni** & & & & & & 0.02 \\
\hline Civil engineering/Uni & & & & & & 0.03 \\
\hline Physics/Uni & & & & & & 0.07 \\
\hline Biology/Uni & & & & & & 0.03 \\
\hline Chemistry/Uni & & & & & & 0.04 \\
\hline Mathematics/Uni & & & & & & 0.04 \\
\hline Computer sciences/Uni & & & & & & 0.06 \\
\hline Linguistics/cultural studies/Uni & & & & & & 0.01 \\
\hline Economics/Uni & & & & & & 0.23 \\
\hline Geology/geography/Uni & & & & & & 0.05 \\
\hline Social/political sciences/Uni & & & & & & 0.07 \\
\hline Arts/Uni & & & & & & 0.05 \\
\hline Magister Artium/Uni & & & & & & 0.10 \\
\hline $\begin{array}{l}\text { Place of post-secondary education: West } \\
\text { Germany (Ref. East Germany) }\end{array}$ & & & & & & 0.86 \\
\hline $\begin{array}{l}\text { Respondents' assessment of importance of } \\
\text { labour market perspectives }\end{array}$ & & & & & & online* \\
\hline $\begin{array}{l}\text { Respondents' assessment of the study } \\
\text { programme }\end{array}$ & & & & & & online* \\
\hline Age: university enrolment & & & & & & 21.26 \\
\hline \multicolumn{7}{|l|}{ Outcome variables } \\
\hline Hourly wage (log.) & & & & & & 2.99 \\
\hline Search duration in months & & & & & & 4.59 \\
\hline Service class & & & & & & 0.63 \\
\hline Type of work experience: share & 0.21 & 0.25 & 0.39 & 0.36 & 0.47 & \\
\hline
\end{tabular}


Table 2 Exemplary assignment model: propensity of having non-field-related work experience before university enrolment

\begin{tabular}{|c|c|}
\hline Age & $1.990^{* * *}$ \\
\hline $\mathrm{Age}^{2}$ & $-0.027 * * *$ \\
\hline Female (ref.: male) & -0.450 \\
\hline Parenthood before eligibility to university & 0.954 \\
\hline Parents with higher education (ref.: no higher education) & -0.255 \\
\hline Year of eligibility to university & -0.079 \\
\hline GPA: Abitur & $0.026^{*}$ \\
\hline \multicolumn{2}{|l|}{ Federal state: Abitur (ref.: North Germany) } \\
\hline North Rhine-Westphalia & -0.332 \\
\hline Hesse/Rhineland-Palatinate & 0.373 \\
\hline Baden-Württemberg & 0.204 \\
\hline Bavaria & 0.090 \\
\hline East Germany & $1.343^{* * *}$ \\
\hline City states & 0.020 \\
\hline Abroad & -0.990 \\
\hline Unknown & $1.967^{* *}$ \\
\hline \multicolumn{2}{|l|}{ Type of Abitur (ref.: abroad) } \\
\hline For all tertiary institutions & 0.146 \\
\hline Fachhochschulen only & 1.378 \\
\hline \multicolumn{2}{|l|}{ Type of upper secondary school (ref.: other) } \\
\hline Gymnasium & -0.781 \\
\hline Vocational & -0.866 \\
\hline Comprehensive & -0.542 \\
\hline Evening school & 0.992 \\
\hline Adult education centre & 0.727 \\
\hline Specialised secondary school & 0.058 \\
\hline Differing vocational types & 0.085 \\
\hline \multicolumn{2}{|l|}{ Interaction terms } \\
\hline Type of Abitur: only Fachhochschule*GPA: Abitur & -0.021 \\
\hline Type of Abitur: only Fachhochschule* Gymnasium & -0.137 \\
\hline $\mathrm{T}$ & 2234 \\
\hline seudo-R ${ }^{2}$ & 0.27 \\
\hline
\end{tabular}

Source: HIS graduate panel 1997, author's own calculations.

${ }^{*} p<0.05 ; * * p 0.01 ; * * * p<0.001$ (two-tailed T-tests) 
Table 3 The ATT of early work experience on labour market performance after graduation

\begin{tabular}{lccc}
\hline & Search duration & Service class & Log hourly wage \\
\hline $\begin{array}{l}\text { Non-field-related work exp. } \\
\text { before studies }\end{array}$ & & & \\
unmatched (t-value) & $0.554(1.13)$ & $-0.031(-1.21)$ & $-0.037(-1.78)$ \\
ATT [z-value] & $-0.783[-0.81]$ & $0.022[0.59]$ & $-0.013[-0.32]$ \\
Observations & 2234 & 2109 & 1978 \\
off common support & 5 & 5 & 5
\end{tabular}

Non-field-related work exp.

during studies

$\begin{array}{lccc}\text { unmatched (t-value) } & 2.272(4.98) & -0.036(-1.44) & -0.030(-1.51) \\ \text { ATT [z-value] } & 1.695[2.97] & -0.033[-1.18] & -0.032[-1.60] \\ \text { Observations } & 2090 & 1966 & 1848 \\ \text { off common support } & 0 & 0 & 1\end{array}$

Field-related work exp. during studies

$\begin{array}{lccc}\text { unmatched (t-value) } & -2.304(-5.62) & 0.063(2.92) & 0.076(4.32) \\ \text { ATT [z-value] } & -1.415[-3.86] & 0.026[1.12] & 0.033[1.86] \\ \text { Observations } & 2234 & 2109 & 1978 \\ \text { off common support } & 2 & 5 & 2\end{array}$

Student assistant

$\begin{array}{llll}\text { unmatched (t-value) } & -2.065(-4.94) & 0.054(2.47) & -0.013(-0.74) \\ \text { ATT [z-value] } & -1.852[-3.98] & 0.050[1.85] & 0.010[0.48] \\ \text { Observations } & 2234 & 2109 & 1978 \\ \text { off common support } & 17 & 11 & 14\end{array}$

Mandatory internship

$\begin{array}{llll}\text { unmatched (t-value) } & -1.347(-3.33) & -0.014(-0.65) & -0.064(-3.70) \\ \text { ATT [z-value] } & -0.373[-0.88] & -0.052[-1.73] & -0.030[-1.34] \\ \text { Observations } & 2227 & 2104 & 1972 \\ \text { off common support } & 42 & 32 & 38\end{array}$

Notes: Kernel matching, Epanechnikov kernel, bandwidth h=0.06; bootstrapping of $\mathrm{z}$-values: $\mathrm{N}=300$ replications; "off common support" are cases which have to be excluded from the analysis due to a lack of cases with similar propensity in the treatment group; ATT = average treatment effect on the treated.

Source: HIS graduate panel 1997, author's own calculations. 


\footnotetext{
${ }^{\mathrm{i}}$ However, they could also regard non-field-related work during schooling in combination with good school marks as a signal for the ability to reconcile different time-consuming activities. Then, non-field-related work experience would have a positive effect on labour market outcomes, too.

ii Mandatory internships have another potentially interesting characteristic. The fact that they are mandatory gives us information about the absence of self-selection into the programme. The statistical control of unobserved heterogeneity is facilitated, since the mandatory nature of the programme removes all possibilities for self-selection into it. Exactly the same mechanism that tells the employer that mandatory internships do not signal higher motivation and effort also serves the researcher as useful information on the self-selection process. If students who completed a mandatory internship are advantaged, this could be interpreted as particularly strong evidence for the hypothesis that work experience per se yields labour market returns.

iii These spells, as well as periods of unemployment, count as search time.

iv In the case of work experience before university enrolment we include all jobs that lasted at least 12 months. This work experience is coded as non-field-related, since these jobs are on a lower skill level.

$\checkmark$ We cannot further differentiate work experience by duration. However, using the Konstanzer Studierendensurvey, a scientific use student dataset, we found out that the number of work hours does not vary between field-related and non-field-related jobs. Only student assistants work, on average, fewer hours. Hence, any effect of this treatment should rather be underestimated.

${ }^{v i}$ All other assignment models can be received from the authors upon request. Testing the balancing properties of our matching models, we performed t-tests on the mean differences on covariates between treatment and control group.
} 